\section{Safe Catgut for Surgical Use}

REFERENCE has been made on two or three occasions in NATURE to the risk of tetanus arising from the use of imperfectly sterilized catgut for surgical ligatures. In order still further to reduce the risk of tetanus infection, the Minister of Health has issued new regulations which require all surgical ligatures and sutures, including catgut, that are not sold under the special licensing arrangements of the Therapeutic Substances Act, to bear a label stating in prescribed terms that efficient sterilization is necessary before use (Statutory Rules and Orders, 1937, No. 767, and Circular 1641. H.M. Stationery Office. 1d.). Catgut which is sold under licence under the Therapeutic Substances Act is free from any possible risk of infection, as its manufacture is strictly controlled and it is properly sterilized before being put on sale.

\section{Bird Protection in Britain}

Dissatisfaction has often been expressed with the legislation by which birds are protected in Great Britain, although there can be little doubt that the law has had the effect of increasing the number of some desirable birds and of extending the survival period of others which were becoming too scarce. The present code of bird protection laws is, however, too complicated and cumbersome, and in several respects it lacks provisions which would much increase its efficiency, so that time and again attempts have been made to consolidate the position. For those who are interested in the present position, particularly in view of the possibility of future legislation, a brief but informative summary of the Acts under which birds are protected in Great Britain has been written by the editor of Bird Notes and News, and a first instalment appears in the autumn number (vol. 17, 167; 1937).

\section{Bronze Bust of Sir Arthur Keith}

IT is proposed to present Sir Arthur Keith with an excellent bronze bust of himself in appreciation of his work in the fields of anatomy, embryology and anthropology. Sir Arthur wishes to hand over the bust to the keeping of the Royal College of Surgeons, should it be found possible to secure it. The sum of $£ 150$ is required to purchase the bust, and contributions are invited towards this amount. Cheques should be made payable, and be sent, to the secretary of the Royal College of Surgeons, Lincoln's Inn Fields, London, W.C.2 ("Arthur Keith Bust Fund"). Sir Arthur Keith has been invited by the College to give a lecture on the ancient types of man which were discovered in Palestine some years ago. This lecture will be given in the College Theatre on February 14, 1938, and it is proposed to present him with the bust on that occasion.

\section{Announcements}

THE following awards have recently been made by the Royal Aeronautical Society : Simms Gold Medal : to Dr. N. A. de Bruyne for his paper on "Plastic
Materials for Aircraft Construction"; Taylor Gold Medal : to G. Mead, for his paper on "Power Plant Trends ; Wakefield Gold Medal : to Dr. G. V. Lachman, for his paper on "Aerodynamic and Structural Features of Tapered Wings" ; Edward Busk Memorial Prize : divided between Major B. C. Carter, for his paper on "Airscrew Blade Vibration", and A. G. Pugsley, for his paper on "Control Surface and Wing Stability Problems"; Pilcher Memorial Prizes : to A. J. Hanson, for his paper on "Critical Speeds of Monoplanes", and C. O. Vernon, for his paper on "Aircraft Performance Estimation".

AT the ordinary meeting of the Institution of Electrical Engineers held on December 16, an oil painting of Mr. Sydney Evershed, by George Harcourt, R.A., was presented to the Institution. The painting was subscribed for by the many business associates and admirers of Mr. Evershed, to commemorate the fiftieth anniversary of his entry into the electrical industry, and it was formally presented, on their behalf, by Lieut.-Col. W. A. Vignoles.

AT the annual general meeting of the London Mathematical Society on November 18, the following were elected officers and council for the session 193738 : President : Prof. E. A. Milne; Vice-Presidents : Prof. G. B. Jeffery, Miss M. L. Cartwright, Mr. J. Hodgkinson; Treasurer: Dr. A. E. Western; Librarian: Prof. H. Hilton; Editor: Prof. G. N. Watson; Secretaries: Mr. F. P. White, Mr. W. L. Ferrar. At the December meeting, the Council received with great regret the resignation of $\mathrm{Mr}$. W. L. Ferrar from the office of secretary, as from January 1, 1938; Mr. P. Hall, King's College, Cambridge, has been appointed to succeed him.

THE twenty-sixth annual Conference of Educational Associations will be held in University College, London, on January 3-10 under the presidency of the Right Hon. Sir Kingsley Wood, M.P. On January 4, Sir Kingsley Wood will deliver his presidential address entitled "Education and Health". A joint conference on "Health in the Schools" will be held on January 6. Further information can be obtained from the Conference Secretary, Gordon House, 29 Gordon Square, W.C.1.

THe Carnegie Institution of Washington has issued a catalogue of its publications, either issued or in press, consisting of a numerical list and a classified list arranged under subjects, with brief descriptive notes on the publications listed. A few copies of the publications still in print are reserved for sale at prices quoted, and those out of print can be consulted in certain libraries throughout the world in which they were deposited on publication. A list of these libraries is obtainable on request. Subjects covered by the catalogue inclide astronomy, botany, chem. istry and physics, engineering, genetics, folk-lore, geology, mathematics, nutrition, philology, terrestrial magnetism and zoology. 